\title{
Brugerinddragelse: forhandlinger af autoritet, relation og viden
}

\author{
Alexandra Ryborg Jønsson, Vibe Hjelholt Baker, Charlotte Bredahl \\ Jacobsen \& Line Hjøllund Pedersen
}

ViBIS

aj@vibis.dk,vhp@vibis.dk,charlotte.bredahl.jacobsen.01@regionh.dk,lip@vibis.dk

Jønsson, A.R. , Baker, V.H., Jacobsen, C.B. \& Pedersen, L.H. (2015). Brugerinddragelse: forhandlinger af autoritet, relation og viden. Tidsskrift for Forskning i Sygdom og Samfund, nr. 22, 5-17

Brugerinddragelse er på alles læber i sundhedsvæsenet. Det står nedskrevet i hospitalernes værdiformuleringer, der bliver afholdt temadage og konferencer om patientinddragelse, der er øget politisk fokus på emnet, og både ledelse og frontpersonale nævner inddragelse som en afgørende kompetence $i$ arbejdet med patienter (Jønsson et al. 2013). Men hvad ligger der egentlig i et så bredtfavnende begreb og hvorfor denne pludselige popularitet? Inden for sundhedsområdet er en dominerende forståelse, at brugerinddragelse er en social reaktion på en paternalistisk tradition. Kernen i denne udlægning er, at det indtil for nogle årtier siden var normen i sundhedsvæsenet at betragte læger som alvidende eksperter, der forventedes at træffe beslutninger på deres patienters vegne ofte med meget lidt eller slet ingen input fra patienterne eller deres pårørende. Patientens eneste opgave var at demonstrere tillid til lægens kompetencer ved lydigt at følge dennes anvisninger, men blev ellers holdt fri for øvrige krav og forventninger. Økonom Erik Riiskjær argumenterer for, at den paternalistiske model stadig spiller en vigtig rolle i den kliniske praksis, fordi den gennem år er indlejret hos både 
sundhedsprofessionelle og patienter. Men samtidig har det øgede fokus på produktivitet i sundhedssektoren skabt nye handlemuligheder for de patienter, som har gennemskuet, at det er muligt at påvirke og være kritiske over for sundhedssystemernes valg (Riiskjær 2014:14-16). I samme tråd påpeger organisationspsyko$\log$ Lene Pedersen, at patienter er i gang med en forvandling fra passive brugere af sundhedssystemet til aktører, der ønsker indflydelse på eget behandlingsforløb (Pedersen 2010:17-28). Spørgsmålet er imidlertid, om brugerinddragelse overhovedet er en ny ting, og hvorfor det ikke er en selvfølge?

Med dette temanummer ønsker Tidsskrift for Forskning i Sygdom og Samfund at bidrage med viden om brugerinddragelse som fænomen i sundhedsvæsenet. Hvorfor oplever vi så stort et fokus på netop dette aspekt af patientforløbet, og hvilke forhold i det biomedicinske felt gør det vanskeligt for sundhedsprofessionelle at inddrage patienter? Er det virkelig et levn fra en paternalistisk tid, hvor det blev anset som noget positivt, at den sundhedsprofessionelle tog ansvar for at fortolke og egenrådigt træffe beslutninger for patienten? Eller er der andet - og mere - på spil? Hvilken rolle spiller brugerinddragelse i praksis, og hvilke konsekvenser har det for relationen mellem behandler og patient? Det er nogle af de spørgsmål, vi vil søge at komme nærmere ind på i dette nummer af Tidsskrift for Forskning i Sygdom og Samfund.

De fire førstnævnte forfattere af denne introduktion - Jønsson, Baker, Jacobsen og Pedersen - er alle ansat ved Videnscenter for Brugerinddragelse i Sundhedsvæsenet (ViBIS). ViBIS blev oprettet i 2011 af Danske Patienter ${ }^{1}$ med støtte fra Trygfonden med det formål at indsamle, bearbejde og videreformidle viden om brugerinddragelse til alle relevante aktører i det danske sundhedssystem. ViBIS har som gæsteredaktion på dette temanummer anlagt en mere akademisk, undersøgende tilgang til begrebet brugerinddragelse, end vi normalt gør brug af $i$ vores daglige arbejde, men har stadig været normativ i udvælgelse og redigering af artiklerne. Det betyder, at ViBIS kriterier for brugerinddragelse i sundhedsvæsenet - hvornår kan man kategorisere initiativer som brugerinddragelse, og hvornår kan man ikke - har været udgangspunkt for vores arbejde med artiklerne til dette nummer. Den normative tilgang har vi samtidig haft for øje ikke måtte gøre os blinde for andre og nye perspektiver på begrebet. To af forfatterne (Jønsson og Baker) har haft det primære gæsteredaktionsarbejde på artiklerne i dette temanummer. De er begge antropologer, men i deres rolle som gæsteredaktører har de først og fremmest trukket på deres indsigt $\mathrm{i}$ forskning om brugerinddragelse - kvantitativ såvel som kvalitativ. 


\section{Fra patient til bruger - eller omvendt?}

Som allerede nævnt argumenteres der ofte for, at patienter er blevet til brugere. Men nogle vil mene, at det snarere er omvendt. Brugerinddragelsesbevægelsen har ikke sine rødder i sundhedsvæsenet, men er lånt fra andre felter. Brugerinddragelse er en del af den offentlige diskurs, der tilskynder borgeren til selvforvaltning, selvledelse og personligt ansvar.

Begrebet har rødder i politologien og samfundsvidenskabelige analyser af politisk deltagelse - 'public participation' - i civilsamfund og demokratiske institutioner. Den amerikanske socialarbejder Sherry Arnstein opstillede i 1969 en model for inddragelse i form af en 'stige' med otte forskellige 'trin' af inddragelse af borgerne i politiske aktiviteter (Arnstein 1969). De to nederste trin på denne 'inddragelsesstige' er inddragelsesformer som ikke reelt inddrager borgerne, kaldet 'manipulation' og 'terapi'. Deres formål er at uddanne eller 'kurere' borgerne ved hjælp af rådgivning og direkte overtalelse, så de opfører sig på måder, der er ønskværdige for magthaverne. De midterste tre trin 'informering', 'konsultation' og 'forsoning' betegner forskellige grader af symbolske handlinger (tokenism), der giver sårbare, svage grupper mulighed for at blive hørt og have en stemme, ved at magthaverne lytter til deres repræsentanter, men som reelt ikke giver dem nogen magt til at sikre, at deres synspunkter får indflydelse på politik eller praksis. Stigens øverste tre trin betegner derimod niveauer af inddragelse med stigende grader af indflydelse på beslutningstagning: Borgerne kan indgå i 'partnerskaber' som sætter dem i stand til at forhandle og indgå i afvejning af fordele og ulemper med traditionelle magthavere, mens de gennem 'uddelegering' og 'borgerstyring' kan opnå mandatflertal i forhold til beslutningsprocesser eller fuld ledelsesmæssig styring over et givent område.

Denne opdeling af inddragelse i politisk beslutningstagning er nyttig, hvis man vil definere, hvilken type inddragelse man ønsker, og hvad man forventer at opnå med den. Modellen giver dog ikke det fulde billede af brugerinddragelse, idet den fokuserer ensidigt på magtfordelingen mellem borger/bruger og magthavere uden at tage andre relevante faktorer, som fx forskellige former for viden og ekspertise, i betragtning. Sådanne faktorer er af stor betydning for borgeres faktiske muligheder for at være inddraget. Stigen er samtidig normativ i sin udformning, idet dens opadgående form giver indtryk af, at de højere trin af inddragelse, med større grad af brugerindflydelse, er bedst i alle situationer. På sundhedsområdet er det indlysende, at dette ikke er tilfældet, idet brugerstyring uden ekspertindblanding her ville kunne have alvorlige konsekvenser, fordi borgerne kun sjældent besid- 
der den nødvendige viden til egenrådigt at træffe beslutninger om specialiseret medicinsk behandling (Tritter 2006). Ligeledes efterlader Arnstein spørgsmålet ubesvaret om, hvordan effektiv brugerinddragelse skal organiseres. Inddragelse kan have visse praktiske implikationer, fx vil mange mennesker fra sårbare og svage grupper ikke være i stand til at deltage i beslutningstagningsprocesser pga. fysiske, psykiske eller sociale begrænsninger. Man kan også tænke sig, at et givent tiltag sigter mod et af de højere trin på inddragelsesstigen, men at strukturelle og organisatoriske forhold gør det svært at gennemføre i praksis, og resultatet derfor bliver en mere symbolsk form for inddragelse, hvor brugere høres, men ikke efterfølgende får reel indflydelse på politik eller praksis.

Brugerinddragelse som begreb i sundhedssystemet handler overordnet om en forandring i opfattelsen af, hvordan relationen mellem behandler og patient skal være; og mere specifikt om hvordan magt og ansvar skal være fordelt mellem de to parter. Brugerinddragelse på sundhedsområdet refererer således specifikt til patienters ret til at have en central plads i behandlingsforløbet. Argumentet fra politisk hold er, at dette kan skabe et bedre samspil mellem den sundhedsprofessionelle og patienten som så igen resulterer i et bedre resultat af behandlingen for patienterne. Undersøgelser har da også vist en række positive effekter af brugerinddragelse, for eksempel i form af større tilfredshed med behandlingen, højere livskvalitet, bedre fysisk og psykisk funktionsniveau, og færre oplevede bivirkninger (Coulter 2012, Stacey et al. 2014). Brugerinddragelse handler således ikke udelukkende om at informere patienter bedre, eller om at patienter skal være bedre klædt på til at forstå, hvad der foregår i mødet med sundhedsvæsenet, men snarere om selve relationen mellem sundhedsprofessionelle og patienter, og de rettigheder og pligter der er knyttet til de respektive roller i denne relation.

\section{Brugerinddragelse og patientroller i historisk perspektiv}

Ser vi på nutidens debat om patientinddragelse i sundhedsvæsenet, har udviklingen af begrebet til dels fundet sted parallelt med borgerinddragelse på det politiske område. Patientinddragelse har blandt andet rødder i den medicinske etik, hvor særligt principperne om ærlighed og respekt for individets autonomi har fået tildelt større betydning gennem de sidste 60 år. Diverse retslige opgør med og offentlig opmærksomhed omkring lægelig misinformation eller embedsmis- 
brug fx i koncentrationslejrene under Anden Verdenskrig, Tuskegee-skandalen i USA $^{2}$, og anvendelse af organer fra afdøde patienter til transplantation eller forskning uden tilladelse fra pårørende ${ }^{3}$, var med til at sætte denne dagsorden. I 1979 fremlagde to filosoffer en overordnet ramme for medicinsk etik, hvor særligt fire forhold blev fremhævet som centrale moralske principper for lægegerningen: Udvise respekt for patientens autonomi som betyder, at patienten har ret til at afvise eller vælge en behandling. Gøre godt, altså handle i patientens bedste interesse. Undgå at volde skade. Udvise retfærdighed, hvilket henviser til fordeling af behandling ved knaphed på ressourcer. Desuden fremhæves ofte lægers pligt til at bevare patient/pårørendes værdighed, og til at fortælle sandheden (Beauchamp \& Childress 1979). Sammen med en gryende erkendelse af betydningen af patientens egen indsats, fx i form af at følge lægens anbefalinger for at opnå gode behandlingsresultater, var dette en af baggrundene for introduktionen af begrebet 'informeret samtykke ${ }^{4}$ som blev lovfæstet i Danmark i løbet af 1990erne og fik sin nuværende form i 1998 (Sundhedsloven 2005).

Selve begrebet brugerinddragelse begynder for alvor at træde igennem i sundhedsvæsenet i de seneste 10-15 år, hvor personer som udvikler, forsker i og styrer sundhedsvæsenet italesætter og fokuserer på brugerinddragelse som en positiv udvikling per se. Eksempelvis erklærede Europarådet i 2000, at involvering i beslutningsprocesser angående sundhedsydelser er en basal og essentiel ret for borgerne i alle demokratiske samfund (Council of Europe 2000). Patienter kræver større indflydelse på de sundhedsydelser de modtager, og informeret samtykke lader til at være utilstrækkeligt. I denne diskurs knyttes brugerinddragelse i sundhedsvæsenet til demokratiske rettigheder, idet demokrati i sig selv er bygget op omkring ideen om borgernes deltagelse som den ultimative kilde til politisk legitimitet.

Men også andre samfundsmæssige forhold har medvirket til at gøre brugerinddragelse til et populært begreb. Særligt efter de økonomiske stramninger i kølvandet på den internationale økonomiske krise i 2008 har begrebet fået politisk medvind (se fx Finanslovsforslag 2014). Dette hænger formodentlig sammen med, at brugerinddragelse spiller fint sammen med det øgede fokus på kvalitet og effektivitet i den offentlige service generelt og i sundhedsvæsenet i særdeleshed. Samtidig peger forskning på, at brugerinddragelse muligvis kan være med til at spare ressourcer på grund af mere effektiv behandling, fordi patienter, der føler sig mere inddraget er mere tilfredse, følger behandlingsanvisningerne bedre, oplever færre bivirkninger og bruger sundhedssystemet mindre (Coulter 2012; Stacey et al. 2014). 
Debatten om brugerinddragelse er også formet af den udvikling, vi gennem de sidste 100 år har set i typen og forekomsten af sygdom. Sygdomsbilledet i den vestlige verden har ændret sig i retning af flere kroniske livsstilssygdomme og højere forekomst af multisygdom (Barnett et al. 2012). Forskningen og den offentlige debats fokus er gradvist blevet udvidet fra hovedsageligt at handle om kliniske resultater som sygelighed og dødelighed til også at omfatte patient-centrerede resultater som livskvalitet og tilfredshed (Shi 2012). Det er blevet vigtigere, hvordan patienterne har det undervejs $\mathrm{i}$ behandlingen, fordi sygdom ikke længere nødvendigvis er noget, man kan blive kureret for eller dø af, men i stedet bliver en fast bestanddel i patienternes hverdagsliv. Patientrollen er derfor også markant anderledes i dag end tidligere. Man er ikke længere nødvendigvis indlagt og fuldstændig underlagt sundhedssystemets kontrol og rutiner, når man er syg. Patienter med for eksempel diabetes, gigt eller depression lever som alle andre raske mennesker i eget hjem. Mange af dem har også overtaget nogle pleje- eller behandlingsopgaver, som de sundhedsprofessionelle udførte før i tiden, som fx selv at måle blodsukker på et apparat derhjemme, tage medicin, skifte forbindinger mv.

I en tid med flere behandlingsmuligheder, flere kronisk syge og længere levetid end nogensinde før, kan brugerinddragelse således medvirke til at legitimere de begrænsninger, økonomiske og demografiske prognoser forudser. Ikke overraskende ses brugerinddragelse derfor af nogle som svaret på de tilsyneladende modstridende krav om mere effektivitet og bedre service i sundhedssektoren.

I takt med populariseringen af brugerinddragelse i sundhedsvæsenet er mange forskelligartede måder at italesætte og begrunde patientinddragelse blomstret op; her har vi kun berørt de overordnede. Desuden er der efterhånden også blevet udviklet en række konkrete metoder og redskaber til at inddrage patienter i praksis, hvoraf nogle, særligt metoden 'shared decision making' (på dansk; fælles beslutningstagning), har fået et så selvstændigt virke, at denne metode i nogle sammenhænge er blevet synonym med inddragelse (Coulter \& Ellins 2012). I 2012 offentliggjorde den engelsk regering eksempelvis sin vision for det engelske sundhedssystem som sigtede mod at sætte patienter og pårørende i centrum i sundhedsvæsenet. Centralt i denne vision er, at alle patienter skal være fuldt involverede i beslutninger om deres egen pleje og behandling, således at princippet 'no decision about me, without me' (ingen beslutning om mig uden mig) - bliver normen i det engelske sundhedsvæsen (Department of Health 2012). Nøgleelementerne i fælles beslutningstagning er, at patient og behandler begge deltager aktivt i beslutningsprocessen; at begge parter deler information om sygdom og behandling med hinanden; at parterne fremlægger deres præferencer for behand- 
ling; og at parterne når til enighed om, hvilken behandling der skal iværksættes (Charles et al. 1997). Spørgsmålet er, om fælles beslutningstagning er en realistisk og ønskværdig inddragelsesform for alle patienter i alle situationer? Eller om et så snævert defineret fokus på patientinddragelse i virkeligheden afskærer nogle patienter fra at være inddraget?

\section{Nye relationer, nye vidensformer}

Patientroller og forventninger til disse formes i en kontekst af interesser, repræsenteret ved patientforeninger, politiske partier, faglige organisationer, medicinalfirmaer og andre interessenter. Forandringer i disse forhold har skabt andre mulige patientroller end den lydige, passive patient. I sin nye bog om det patientcentrerede sundhedsvæsen argumenterer Erik Riiskjær eksempelvis for, at man i den offentlige debat foruden den lydige patient kan spore referencer til hele syv patientroller; den medproducerende patient, den rettighedsbærende patient, den empowerede patient, patienten som risikant, som informationssøger, som kunde og som politiker. Disse forskellige roller indebærer forskellige rettigheder og pligter. For patienten kan det derfor opleves som om, der er meget forskelligartede - og potentielt modstridende - forventninger til, hvordan man skal opføre sig i relation til forskellige aktører for at være 'en god patient' (Riiskjær 2014). Lægens rolle har tilsvarende fået flere aspekter; på den lægelige videreuddannelse undervises medicinstuderende således i de kompetencer, der kræves i de syv lægeroller: 'medicinsk ekspert', 'kommunikator', 'samarbejder', 'leder/administrator', 'sundhedsfremmer', 'akademiker' og 'professionel' (Speciallægekommissionen 2000, Sundhedsstyrelsen 2013). Også her kan der knytte sig forskellige forventninger til de forskellige roller: eksempelvis kan en leder/administrator skulle forholde sig til organisatoriske problemstillinger som ville være uden betydning for en akademisk læge, der til gengæld ville være mere optaget af, hvorvidt behandlingen følger videnskabelige retningslinjer. Spørgsmålet er, hvorvidt disse mange patient- og lægeroller passer sammen, eller om de blot øger kompleksiteten og gør det vanskeligere at afgøre, hvordan den ideelle relation mellem læge og patient skal udfolde sig?

Læge- og patient- eller sygerollen, og de forventninger og pligter der knytter sig til disse roller, blev beskrevet allerede i 1951 af Talcott Parsons (Parsons 1951). Siden blev denne tilgang udfordret af andre sociologer, blandt andre An- 
selm Strauss som begyndte at beskrive oplevelsen af sygdom fra patientens perspektiv. Strauss så patienter som aktive aktører - ikke blot passive modtagere af behandling - og læge-patientforholdet som et sammenstød mellem to forskellige perspektiver på sygdom og behandling. Strauss og hans kollegaer undersøgte de forskellige former for 'arbejde', som patienter og pårørende udfører, og anerkendte dermed også, at pårørende bidrager med en stor del af plejen og omsorgen for (kronisk) syge patienter. Når sygdom rammer, er det ikke kun den syge, der står overfor nye problemer og opgaver, der skal håndteres - det gør de pårørende også (Corbin \& Strauss 1985, Corbin \& Strauss 1988).

Synet på patienten i samspillet og de roller, denne kan indtage, har således skiftet gennem tiderne. Fra Strauss' projekt med at vise at patienter påtager sig aktive roller - de er ikke passive modtagere - til Erik Riiskjærs spejling af de forskellige måder at være aktiv og professionel læge i de forskellige måder at være aktiv og inddraget patient. På samme måde udvikler diskursen om brugerinddragelse sig og sætter nye begreber i spil.

\section{Autoritet og faglighed}

Når roller og viden er til forhandling, sætter det også autoritet og fagligheden på spil hos de som før havde monopol på magten i sundhedsvæsenet. Det resulterer ikke nødvendigvis i en direkte konflikt mellem sundhedsprofessionelle og patienter, men kan spores i den implicitte modstand, der udtrykkes af mange sundhedsprofessionelle (Jønsson et al. 2013: 26-31). Særligt "tid" bliver fremhævet som årsag til, hvorfor patienter og pårørende ikke inddrages i højere grad. Er det et udtryk for, at arbejdspresset i sundhedsvæsenet er blevet for højt, og at de sundhedsprofessionelle derfor oplever det som vanskeligt at lytte, tage patientens synspunkter ind, og måske i det hele taget at ændre deres praksis? I et fænomenologisk perspektiv kan den kvalitative forskning anerkende de sundhedsprofessionelles oplevelse af at mangle tid, men antropologiens blik på det partikulære kan give os en dybere forståelse af, hvad der er på spil. Antropologen Maya Nyborg beskriver eksempelvis i sit speciale, hvordan sygeplejerskers klager over ikke at have tid til brugerinddragelse, ikke kun er en klage over antallet af minutter. Det er også en klage over en arbejdsform, som fragmenterer patientkontakten så meget, at det er umuligt at få en oplevelse af at skabe et fælles meningsfuldt forløb sammen med 
patienten. Og det er netop den oplevelse, som de forbinder med at være brugerinddragende (Nyborg 2015).

Men også fagligheden udfordres, når nye roller defineres, og patienters viden tillægges større betydning end tidligere. Dette kan føre til konflikter, eller omvendt resultere $i$, at patienterne undlader at bringe deres viden på banen, af frygt for at dette skal blive opfattet som en underkendelse af de fagprofessionelles autoritet og kompetence (Joseph-Williams et al. 2014).

Netop implementeringen af begrebet brugerinddragelse i praksis; dets mangfoldighed, implikationer og udfordringer, har været drivkraften bag dette temanummer. Vi har kastet nettet ud blandt kvalitative forskere, der beskæftiger sig med sundhedsvæsenet for at undersøge hvilke forskellige analytiske vinkler på brugerinddragelse, der kan hjælpe os til en bedre forståelse af begrebet og dets udmøntning i praksis. Fælles for artiklernes empiriske emner er fokus på de begrænsninger, brugerinddragelse har. De viser empirisk, hvordan begrebet på forskellige måder skaber problemer, når det bliver sat i spil i forhold til de andre begreber, der allerede er strukturerende for sundhedsvæsenets rammer og tilbud.

\section{Temanummerets artikler: kritiske perspektiver på brugerinddragelse}

Flere artikler i temanummeret tager udgangspunkt i de institutionelle og organisatoriske logikker, der har indflydelse på brugerinddragelse. Temanummerets første artikel "The Two Faces of User Involvement" stiller skarpt på, hvordan patienters viden forhandles i udviklingen af et patientundervisningsforløb versus de rammer, der er sat for inddragelsen. Kristensen et al. tager udgangspunkt i resultater fra et etnografisk feltarbejde, der fulgte et patientundervisningsprojekt. Forfatterne beskriver, hvordan patienternes viden om en hverdag med sygdom på den ene side var kernen i selv tanken om inddragelse i projektet, mens de lokale institutionelle logikker og projektorganiseringen på den anden side var bygget op omkring nogle andre forestillinger om, hvordan og med hvilken form for viden patienter skulle inddrages.

De efterfølgende artikler handler om de implikationer, brugerinddragelse har for relationen mellem sundhedsprofessionelle og patienter. Terkildsen og Wittrups artikel "Negotiating experience in patient involvement-challenges of practicing storytelling in health care conversations" er baseret på en narrativ analyse af in- 
terkulturelle sundhedssamtaler. Forfatterne viser, at ikke alle patientfortællinger får plads på trods af den formulerede målsætning om at inddrage patienterne og lade deres perspektiv være styrende for problemformulering og løsningsforslag. Brugerinddragelse sættes hermed ind i en antropologisk debat, hvor den levede erfaring med sygdom ses som en partikulær social form, der forhandles i en social kontekst, og derved synliggør grænser for, hvordan erfaring med sygdom kan udtrykkes socialt gennem patientfortællinger.

Et andet eksempel på, hvordan brugerinddragelse udfordrer læge-patient relationen, ses i Jacobsen, Baker og Martins artikel "Who knows best? Negotiations of knowledge in clinical decision making". Her viser forfatterne, hvordan konflikter mellem patienter og sundhedsprofessionelle opstår, når patienter tilbageholder information for at undgå at udfordre klinikeres autoritet, eller omvendt, bruger farmakologisk viden i argumenter for valg af behandling. Forfatterne argumenterer empirisk for, at mange patienter har ikke bare personlige erfaringer, men også stor farmakologisk viden om medicinsk behandling enten qua deres egen professionelle baggrund, eller som de har opsamlet fra forskellige kilder gennem et langt liv med kronisk sygdom. Konflikterne mellem læger og patienter handler her om, hvem der har ret til at gøre brug af farmakologisk viden. Brugerinddragelse, særligt metoden 'shared decision making', forudsætter dels at læge og patient har to forskellige former for viden - henholdsvis lægefaglig viden og personlig erfaring med sygdom og behandling, men også at de institutionelle rammer og arbejdsrutiner muliggør, at patientens viden kan få betydning for beslutninger. Når disse to forudsætninger ikke er tilstede, er der grobund for konflikt.

Netop denne særlige patientviden er også genstand for Ørtenblad, Jønsson og Meilliers artikel om mennesker med flere kroniske sygdomme - multisygdom. I artiklen "Komplekse liv. Patientinddragelse som vej til et bedre hverdagsliv for multisyge" viser forfatterne med udgangspunkt i tre cases, hvordan mennesker med multisygdom navigerer og prioriterer behandling og egenomsorg med udgangspunkt i deres hverdagsliv. Forfatterne bruger social identitet, relationer og sygdomsforståelse som centrale begreber i forståelsen af multisyges oplevelser af kompleksitet i sygdomsforløbene. Der argumenteres for, at særligt multisyge patienter har brug for at blive inddraget $\mathrm{i}$ beslutninger om behandling og pleje, fordi kompleksiteten af deres sygdomsforløb påvirker hverdagen i betydelig grad.

Temanummerets afsluttende artikel fokuserer på ledelses rolle, når brugerinddragelse sættes på dagsordenen i en lokal, organisatorisk kontekst. Holm-Petersen og Navne påpeger i artiklen "Ledelse som nøgle til implementering af brugerinddragelse - 3 modeller til nye organiseringsformer" nogle af de udfordringer, 
sundhedsprofessionelle og ledere oplever, når de forsøger at omsætte begrebet brugerinddragelse til praksis og integrere det i deres daglige arbejde. Artiklen bygger på en analyse af policydokumenter og best practice undersøgelser, der viser, at brugerinddragelse er et begreb med mange facetter, der ikke alle peger $\mathrm{i}$ samme retning. Samtidig er sundhedsvæsenet en arena, hvor mange andre politiske, ledelsesmæssige og ideologiske kampe udkæmpes. For sundhedsvæsenets ledelsespersoner opleves det som særligt udfordrende, at brugerinddragelse ikke bare kræver nye sundhedsprofessionelle kompetencer og nye måder at indgå i relationer til patienter og pårørende, men også nye måder at organisere arbejdet på. Med udgangspunkt i tre forskellige inddragelsesmodeller, med hver sin organisering af relationer mellem sundhedsprofessionelle og sundhedsvæsenets brugere, argumenterer forfatterne for, at ledelsens opgave derfor er at medvirke til en gentænkning af de etablerede roller og identiteter i sundhedsvæsenet.

Artiklerne belyser i deres helhed de udfordringer og implikationer, der findes ved brugerinddragelse, beskrevet ud fra både patienter, sundhedsprofessionelles og lederes synspunkt. En mindre belyst side i temanummeret er en komparativ vurdering, der sætter begrebet ind i en større medicinsk antropologisk kontekst. Mens der bliver fokuseret på aktørerne i forhold til brugerinddragelse, ville det også være relevant at kigge på, hvilke udfordringer der er ved brugerinddragelse for eksempel i forhold til social ulighed. Man kan rejse spørgsmålet om, hvilke skyggesider brugerinddragelse har - er brugerinddragelse kun mulig for de bedst uddannede patienter, og er der forskel på inddragelsen geografisk? Man kan også spørge, hvilken betydning køn og alder har i forhold til at være inddraget? Dette temanummer er tænkt som et bidrag til 'den blinde plet på landkortet' over kvalitativ forskning i brugerinddragelse i Danmark. Artiklerne i temanummeret vidner om både positive og negative konsekvenser af brugerinddragelse og kalder på mere forskning. Hvis brugerinddragelse er kommet for at blive, er vi kun lige begyndt.

\section{Noter}

1: Danske Patienter er paraplyorganisation for 19 danske patientforeninger, der arbejder for at fremme patienters rettigheder og vilkår i sundhedsvæsenet.

2: Tuskegee-studiet var et forsøg som over 6 måneder skulle kortlægge effekten af ubehandlet syfilis hos sorte mænd. Deltagerne i undersøgelsen blev ikke informeret om studiets formål og modtog ikke behandling for syfilis, selv efter at en sådan blev fundet og taget i almindelig brug. http://www.cdc.gov/tuskegee/timeline.htm 
3: Fx skandalen på Alder Hey Childrens Hospital i Liverpool, England, hvor organer fra 850 døde børn blev anvendt til forskning uden forældrenes samtykke i perioden 1988 til 1995. http://en.wikipedia.org/wiki/Alder_Hey_organs_scandal

4: Informeret samtykke indebærer, at patienter skal give tilsagn om (oftest i form af en underskrevet erklæring), at de har forstået og accepterer fordele og ulemper ved den foreslåede behandling, før behandlingen kan påbegyndes.

\section{Referencer}

Arnstein SR. (1969). A ladder of citizen participation. Journal of the American Planning Association, vol 35, no 4 (July):216-224

Barnett K, Mercer SW, Norbury M, Watt G, Wyke S \& Guthrie B (2012). Epidemiology of multimorbidity and implications for health care, research, and medical education: a cross-sectional study. Lancet. Jul. 7;380:37-43

Beauchamp TL \& Childress JF. (1979). 'Principles of biomedical ethics' 1979. Oxford University Press, Oxford 2009, 6 ed.

Charles C, Gafni A \& Whelan T. (1997). Shared decision making in the medical encounter: What does it mean (or it takes at least two to tango). Social Science and Medicine. vol 44, no 5:681-692,

Corbin J \& Strauss AL. (1985) Managing chronic illness at home: three lines of work. Qualitative Sociology 8:224-47

Corbin J \& Strauss AL. (1988) Unending Work and Care: Managing Chronic Illness at Home. San Francisco; Jossey-Bass

Coulter A. (2012). Patient Engagement - What Works? Journal of Ambulatory Care Management vol 35, no 2:80-89

Coulter A \& Collins A. (2012). Making Shared Decision-Making a reality - No decision about me, without me. ISBN: 9781857176247 . The King's Fund

Council of Europe (2000). The development of structures for citizen and patient participation in the decision-making process affecting health care. Recommendation adopted by the Committee of Ministers of the Council of Europe, February, 24, Strasbourg, France.

Joseph-Williams, N; Elwyn G; Edwards A (2014): Knowledge is not power for patients. A systematic review and synthesis of patient-reported barriers and facilitators to shared decision making. Patient Ecuation and Counselling, 94, pp. 291-309.

Jönsson ABR, Nyborg MJG, Pedersen VH, Pedersen LH, Wandel A, Freil M. (2013) Sundhedsprofessionelles forståelser af patientinddragelse - en kvalitativ undersøgelse. København. ISBN: 978-87-996473-0-9: Videnscenter for Brugerinddragelse i Sundhedsvæsenet

Massé R \& Légaré F. (2001). The limitations of a negotiation model for perimenopausal women. Sociology of Health $\mathcal{E}$ Illness, vol 23, no 1: 44-64

Nyborg, Maya J.G. (2015). At se mennesket i patienten. En antropologisk undersøgelse af hvordan patientinddragelse forstås og praktiseres af danske sundhedsprofessionelle. Speciale, Institut for Antropologi, Københavns Universitet.

Parsons T. (1951). The social system. Routledge \& Kegan Paul, London 
Pedersen L (2011). Patientinddragelse - refleksion, læring, innovation og ledelse:17-28. ISBN: 9788741254210. Hans Reitzels Forlag

Riiskjær E. (2014). Patienten som partner - En nødvendig idé med ringe plads. ISBN: 9788776748210. School of Business and Social Science. Aarhus Universitet. Syddansk Universitetsforlag

Regeringen. Vækst og balance, Finanslovsforslag 2014

Speciallægekommissionen. Fremtidens speciallæge (2000)

Sundhedsstyrelsen (2005). »Sundhedsloven« lov nr. 546 af 24. juni 2005. »Vejledning om information og samtykke og om videregivelse af helbredsoplysninger mv.« VEJ nr. 161 af 16/09/1998. Sundhedsstyrelsen

Sundhedsstyrelsen. (2013). De syv lægeroller. ISBN: 9788771045109. Sundhedsstyrelsen

Shi L. (2012) The Impact of Primary Care: A Focused Review. Scientifica Volume 2012 (2012), Article ID 432892

Stacey D, Légaré F, Col NF, Bennett CL, Barry MJ, Eden KB, Holmes-Rovner M, LlewellynThomas H, Lyddiatt A, Thomson R, Trevena L \& Wu JH. (2014). Decision aids for people facing health treatment or screening decisions. Cochrane Database Systematic Review. 2014 Jan 28;1: CD001431

Tritter, JQ \& MCCallum A. (2006). The snakes and ladders of user involvement: Moving beyond Arnstein. Health Policy 76:156-168 